\title{
Effects of Air and Soil Temperature on Vegetative Growth and Flower Bud Differentiation of Satsuma Mandarin Trees
}

\author{
Roedhy Poerwanto*, Hiroshi Inoue, Yoshinori Ikoma and Ikuo Kataoka \\ Faculty of Agriculture, Kagawa University, Miki-Cho, Kita-Gun, Kagawa 761-07
}

\begin{abstract}
Summary
One-year-old satsuma mandarin (Citrus unshiu Marc. cv. Okitsu Wase) trees budded onto trifoliate orange rootstocks were subjected to different soil temperature $(15,20,25$ and $\left.30^{\circ} \mathrm{C}\right)$ and air temperature treatments $\left(25^{\circ} \mathrm{C}\right.$ in Experiment $\mathrm{I}$, and 15 and $30^{\circ} \mathrm{C}$ in Experiment II) for 6 or 7 months. The effects of air and soil temperatures on vegetative growth and flower bud differentiation were investigated.

The number of flushes and total length of the shoots increased with rising soil temperatures. When soil temperatures were above $20^{\circ} \mathrm{C}$, the number of flushes at an air temperature of $15^{\circ} \mathrm{C}$ was less than at $30^{\circ} \mathrm{C}$. The length of spring shoots at an air temperature of $15^{\circ} \mathrm{C}$ was longer than at $30^{\circ} \mathrm{C}$. However, due to the trees at air temperature of $30^{\circ} \mathrm{C}$ having more growth cycle flushes, the total length of the shoots did not differ among treatments. The dry weight of the trees increased with increases in both air and soil temperatures. Both low air and low soil temperatures affected flower induction greatly. At an air temperature of $30^{\circ} \mathrm{C}$, flower buds developed only at soil temperatures of 15 and $30^{\circ} \mathrm{C}$. At an air temperature of $15^{\circ} \mathrm{C}$, flower buds developed even when the soil, temperature was $30^{\circ} \mathrm{C}$. Trees with air/soil temperatures of $25 / 30$, $30 / 25$ and $30 / 30^{\circ} \mathrm{C}$ did not bear any flower buds. The effects of temperature on mineral nutrient content were slight. The roles of soil and air temperature on vegetative growth and flower formation are briefly discussed.
\end{abstract}

\section{Introduction}

Flower bud differentiation in satsuma mandarin is known to be greatly affected by temperature. Cold winters have often been considered as main factor affecting flower induction, but they are not essential, as recent researches have indicated that flower initiation can occur at constant temperatures of 15 or $20^{\circ} \mathrm{C}(6,7)$. On the contrary, temperatures as high as $30^{\circ} \mathrm{C}$ advanced only vegetative growth. Root stress may be one factor affecting flower induction, as it has been reported that drought or root pruning induces flower buds in citrus $(5,8,15,18,19)$. Monselise(12) stated that there is a correlation between flower induction and depression of root growth. We reported

Received for publication May 16, 1988.

Parts of this paper were presented at the 1987 and 1988 Autumn meeting of Japan. Soc. Hort. Sci.

* Present address: Department of Agronomy, Faculty of Agriculture, Bogor Agricultural University, Jl. Pajajaran, Bogor, Indonesia. previously that both the root and shoot growth of satsuma mandarin on trifoliate orange were markedly restricted when the trees were grown at $15^{\circ} \mathrm{C}(17)$. It seems likely that the physiological stress on the root system caused by cool temperatures acts on flower induction indirectly.

These studies were conducted to get basic information on the management of air and soil temperature in order to control the balance of vegetative and generative growth in satsuma mandarin.

\section{Materials and Methods}

Uniform one-year-old 'Okitsu Wase' satsuma mandarin trees budded onto trifoliate orange rootstocks were used. The trees were planted in Wagner's pots $(265 \mathrm{~mm}$ in diameter $\times 300$ $\mathrm{mm}$ in depth) filled with a mixture of granite soil and bark compost $(2: 1)$ in late March of 1986 and 1987. They were grown under field conditions until the experiments started.

In Experiment I, the air temperature was held constant at $25^{\circ} \mathrm{C}$ for all trees. Trees were 
divided into groups of three, and each group was subjected to a different soil temperature, that is, 15,2025 and $30^{\circ} \mathrm{C}$. In this report, these treatments will be referred to as: $25 / 15$, $25 / 20,25 / 25$ and $25 / 30^{\circ} \mathrm{C}$. The treatments were initiated on May 21, 1986 and were continued until November 10, 1986. The trees were fertilized with ammonium sulfate, superphosphate and potassium sulfate equivalent to $9.8 \mathrm{~g} \mathrm{~N}, 9.8 \mathrm{~g} \mathrm{P}_{2} \mathrm{O}_{5}$ and $9.8 \mathrm{~g} \mathrm{~K}_{2} \mathrm{O}$ per tree.

Temperature treatments in Experiment II were done from April 21 to November 30, 1987. The trees were divided as before, and some were subjected to air temperature of 15 ${ }^{\circ} \mathrm{C}$ and others to $30^{\circ} \mathrm{C}$. At each air temperature, the trees were also subjected to different soil temperatures of $15,20,25$ and $30^{\circ} \mathrm{C}$. These treatments will be referred to as $15 / 15$, $15 / 20,15 / 25,15 / 30,30 / 15,30 / 20,30 / 25,30 / 30$ ${ }^{\circ} \mathrm{C}$. The trees were fertilized with an $8-8-8$ fertilizer $(\mathrm{N}-\mathrm{P}-\mathrm{K})$ equivalent to $5.6 \mathrm{~g} \mathrm{~N}, 5.6$ $\mathrm{g}_{2} \mathrm{O}_{5}$ and $5.6 \mathrm{~g} \mathrm{~K}_{2} \mathrm{O}$ per tree.

Soil temperatures were maintained by placing the pots in separate water baths $(640 \times 440 \times$ $380 \mathrm{~mm}$ ) equipped with heating and cooling devices. The surface of each bath was covered with a styrofoam plate, with only small openings for tree trunks and circulating tubes(16).

In both experiments, all the trees were defoliated and then exposed to $25^{\circ} \mathrm{C}$ (on November 11, 1986 in Experiment I and on December 1, 1987 in Experiment II) to observe flower bud development. At the end of the experiment, all trees were harvested. The spring leaves and fibrous roots were dried and ground for nutrient analysis.

Nitrogen content was analyzed using the Kjeldahl method. Samples were wet-digested for phosphorus and cation analysis. Phosphorus content was determined from sample stock solutions by spectrophotometry (vanadatemolybdate-yellow method), potassium content by flame photometry, and calcium, magnesium, manganese and zinc contents by atomic absorption spectrophotometry (16).

\section{Results}

\section{Shoot Growth}

The trees had three growth flushes at $25 / 30$ ${ }^{\circ} \mathrm{C}$, two at $25 / 25$ and $25 / 20^{\circ} \mathrm{C}$ and one at $25 / 15$ ${ }^{\circ} \mathrm{C}$. The length of the spring shoots was not
Table 1. Effect of soil temperature on shoot length of satsuma mandarin in Experiment I (cm).

\begin{tabular}{ccccc}
\hline \hline $\begin{array}{c}\text { Soil } \\
\text { temperature }\end{array}$ & $\begin{array}{c}\text { First } \\
\text { growth } \\
\text { cycle }\end{array}$ & $\begin{array}{c}\text { Second } \\
\text { growth } \\
\text { cycle }\end{array}$ & $\begin{array}{c}\text { Third } \\
\text { growth } \\
\text { cycle }\end{array}$ & $\begin{array}{c}\text { Total } \\
\text { growth }\end{array}$ \\
\hline $15^{\circ} \mathrm{C}$ & $103.73 \mathrm{~ns}^{\mathrm{z}}$ & - & - & $103.73 \mathrm{c}$ \\
$20^{\circ} \mathrm{C}$ & 135.43 & 6.93 & - & $142.36 \mathrm{bc}$ \\
$25^{\circ} \mathrm{C}$ & 116.23 & 174.13 & - & $290.36 \mathrm{ab}$ \\
$30^{\circ} \mathrm{C}$ & 115.70 & 217.93 & 122.40 & $465.07 \mathrm{a}$ \\
\hline
\end{tabular}

z Different letters within columns indicate significant differences at $1 \%$ level; ns indicates non-significant at $5 \%$ level.

y Air temperature was $25^{\circ} \mathrm{C}$.

Table 2. Effect of air and soil temperature on shoot length of satsuma mandarin in Experiment II $(\mathrm{cm})$.

\begin{tabular}{lrccr}
\hline \hline $\begin{array}{c}\text { Air/soil } \\
\text { temperature }\end{array}$ & $\begin{array}{c}\text { First } \\
\text { growth } \\
\text { cycle }\end{array}$ & $\begin{array}{c}\text { Second } \\
\text { growth } \\
\text { cycle }\end{array}$ & $\begin{array}{c}\text { Third } \\
\text { growth } \\
\text { cycle }\end{array}$ & $\begin{array}{c}\text { Total } \\
\text { growth }\end{array}$ \\
\hline $15 / 15^{\circ} \mathrm{C}$ & 85.53 & - & - & 85.52 \\
$15 / 20^{\circ} \mathrm{C}$ & 172.73 & - & - & 172.73 \\
$15 / 25^{\circ} \mathrm{C}$ & 176.03 & 163.50 & - & 339.53 \\
$15 / 30^{\circ} \mathrm{C}$ & 211.13 & 179.13 & - & 423.60 \\
& & & & \\
$30 / 15^{\circ} \mathrm{C}$ & 49.13 & - & - & 49.13 \\
$30 / 20^{\circ} \mathrm{C}$ & 100.07 & 39.97 & 51.53 & 187.57 \\
$30 / 25^{\circ} \mathrm{C}$ & 114.63 & 169.60 & 126.33 & 410.57 \\
$30 / 30^{\circ} \mathrm{C}$ & 147.90 & 165.07 & 106.73 & 419.70 \\
Significance & & & & \\
-Air & $* *$ & & & $\mathrm{~ns}$ \\
-Soil & $* *$ & & & $* *$ \\
-Interaction & $\mathrm{ns}$ & & & $\mathrm{ns}$ \\
\hline
\end{tabular}

$\mathrm{z}$ ns indicates non-significant at $5 \%$ level;

** significant at $1 \%$ level.

significantly different between treatments, because soil temperature treatments were initiated after the growth of spring shoots ceased. However, total shoot length was significantly different (Table 1).

The trees at $15 / 15,15 / 20$ and $30 / 15^{\circ} \mathrm{C}$ developed only spring shoots. Those at $15 / 25$ and $15 / 30^{\circ} \mathrm{C}$ developed both spring and summer shoots, and those at $30 / 20,30 / 25$ and $30 / 30^{\circ} \mathrm{C}$ also developed autumn shoots. The length of spring shoots and the total length of the shoots increased with rising soil temperatures. Under the same soil temperature conditions, spring shoots at an air temperature of $15^{\circ} \mathrm{C}$ were longer than those at $30^{\circ} \mathrm{C}$. However, due to the trees in the $30^{\circ} \mathrm{C}$ growth chamber having more growth flushes, the total length of shoots was not different (Table 2). 


\section{Dry Matter Production}

The results of Experiment I showed that the dry matter of the trees increased as soil temperatures rose from 15 to $30^{\circ} \mathrm{C}$ (Table 3). Dry weight of the fibrous roots was lowest at $25 / 15^{\circ} \mathrm{C}$ and greatest at $25 / 30^{\circ} \mathrm{C}$. These values were significantly different from those at $25 / 20$ and $25 / 25^{\circ} \mathrm{C}$ (Table 4 ).

In Experiment II, total dry matter of the trees, and dry weight of the roots and stems increased with rising air and soil temperatures. Dry weight of the leaves increased with rising
Table 3. Effect of soil temperature on dry matter produced by satsuma mandarin in Experiment I (g).

\begin{tabular}{ccccc}
\hline $\begin{array}{c}\text { Soil } \\
\text { temperature }\end{array}$ & Roots & Stems & Leaves & Total \\
\hline $15^{\circ} \mathrm{C}$ & $32.77 \mathrm{~b}^{\mathrm{z}}$ & $33.46 \mathrm{~b}$ & $7.07 \mathrm{c}$ & $73.30 \mathrm{~b}$ \\
$20^{\circ} \mathrm{C}$ & $37.47 \mathrm{~b}$ & $39.07 \mathrm{~b}$ & $14.67 \mathrm{bc}$ & $91.21 \mathrm{~b}$ \\
$25^{\circ} \mathrm{C}$ & $43.53 \mathrm{ab}$ & $52.37 \mathrm{~b}$ & $33.07 \mathrm{ab}$ & $128.97 \mathrm{a}$ \\
$30^{\circ} \mathrm{C}$ & $64.23 \mathrm{a}$ & $105.30 \mathrm{a}$ & $54.70 \mathrm{a}$ & $224.23 \mathrm{a}$ \\
\hline
\end{tabular}

z The same as Table 1.

y Air temperature was $25^{\circ} \mathrm{C}$.

Table 4. Effect of soil temperature on dry weight of satsuma mandarin roots in Experiment I (g).

\begin{tabular}{llllll}
\hline \hline Soil temperature & $\begin{array}{c}\text { Fibrous roots } \\
(\phi \leqq 2 \mathrm{~mm})\end{array}$ & $\begin{array}{c}\text { Small roots } \\
(2<\phi \leqq 5 \mathrm{~mm})\end{array}$ & $\begin{array}{l}\text { Large roots } \\
(\phi>5 \mathrm{~mm})\end{array}$ & Taproots & Total \\
\hline $15^{\circ} \mathrm{C}$ & $3.80 \mathrm{c}^{\mathrm{z}}$ & $4.27 \mathrm{~ns}$ & $10.80 \mathrm{~ns}$ & $13.90 \mathrm{~b}$ & $32.77 \mathrm{~b}$ \\
$20^{\circ} \mathrm{C}$ & $10.03 \mathrm{~b}$ & 3.83 & 11.13 & $12.47 \mathrm{~b}$ & $37.47 \mathrm{~b}$ \\
$25^{\circ} \mathrm{C}$ & $11.60 \mathrm{~b}$ & 4.57 & 14.10 & $13.27 \mathrm{~b}$ & $43.53 \mathrm{ab}$ \\
$30^{\circ} \mathrm{C}$ & $18.07 \mathrm{a}$ & 8.23 & 17.40 & $20.53 \mathrm{a}$ & $64.23 \mathrm{a}$ \\
\hline
\end{tabular}

z The same as Teble 1.

y Air temperature was $25^{\circ} \mathrm{C}$.

soil temperatures, but air temperature did not significantly affect the dry weights (Table 5). Dry weight of the fibrous roots increased with both rising soil and air temperatures. At an air temperature of $30^{\circ} \mathrm{C}$, the dry weight of the fibrous roots increased greatly with rising soil temperatures, but at an air temperature of 15 ${ }^{\circ} \mathrm{C}$ there were only slight increases (Table 6).

Table 5. Effect of air and soil temperature on dry matter produced by satsuma mandarin in Experiment II (g).

\begin{tabular}{ccccc}
\hline $\begin{array}{l}\text { Air/Soil } \\
\text { temperature }\end{array}$ & Roots & Stems & Leaves & Total \\
\hline $15 / 15^{\circ} \mathrm{C}$ & 19.98 & 18.13 & 10.39 & 48.48 \\
$15 / 20^{\circ} \mathrm{C}$ & 30.51 & 29.85 & 20.64 & 81.00 \\
$15 / 25^{\circ} \mathrm{C}$ & 34.37 & 34.46 & 48.13 & 116.96 \\
$15 / 30^{\circ} \mathrm{C}$ & 41.04 & 46.04 & 64.47 & 151.55 \\
& & & & \\
$30 / 15^{\circ} \mathrm{C}$ & 33.50 & 25.39 & 11.18 & 70.07 \\
$30 / 20^{\circ} \mathrm{C}$ & 33.28 & 33.31 & $34.2 \mathrm{I}$ & 100.80 \\
$30 / 25^{\circ} \mathrm{C}$ & 42.07 & 50.46 & 48.50 & 141.03 \\
$30 / 30^{\circ} \mathrm{C}$ & 50.99 & 58.30 & 60.47 & 169.76 \\
Significance & & & & \\
- Air & $* *$ & $* *$ & $\mathrm{~ns}$ & $*$ \\
-Soil & $* *$ & $* *$ & $* *$ & $* *$ \\
-Interaction & $\mathrm{ns}$ & $\mathrm{ns}$ & $* *$ & $\mathrm{~ns}$ \\
\hline
\end{tabular}

${ }^{2}$ ns indicates non-significant at $5 \%$ level;

* significant at $5 \%$ level; **. significant at $1 \%$ level.

\section{Flower Bud Differentiation}

In Experiment $\mathrm{I}$ the trees at $25 / 15^{\circ} \mathrm{C}$ developed flower buds in early October of 1986 and began to blossom in mid-October. Negligible numbers of flower buds developed on the trees at $25 / 20$ and $25 / 25^{\circ} \mathrm{C}$ in late October of 1986. At an air temperature of $25^{\circ} \mathrm{C}$, raising the soil temperature from 15 to $30^{\circ} \mathrm{C}$ decreased the ratio of flower buds to total sprouting buds. Only negligible numbers of flomer buds developed at $25 / 30^{\circ} \mathrm{C}$ (Table 7 ).

In Experiment II, all trees at an air temperature of $15^{\circ} \mathrm{C}$ developed flower buds during August and September. On the other hand, The trees at $30 / 15$ and $30 / 20^{\circ} \mathrm{C}$ developed flower buds after they were defoliated and transferred to a $25^{\circ} \mathrm{C}$ growth chamber on December 1 , 1987.

Table 8 shows that flower buds formed on all the trees at an air temperature of $15^{\circ} \mathrm{C}$, even when the soil temperature was $30^{\circ} \mathrm{C}$. The number of flower buds at $15 / 25$ and $15 / 30$ ${ }^{\circ} \mathrm{C}$, however, was significantly lower than at $15 / 15$ and $15 / 20^{\circ} \mathrm{C}$. At an air temperature of $30^{\circ} \mathrm{C}$, flower buds formed only when soil temperatures were 15 and $20^{\circ} \mathrm{C}$. The number of vegetative shoots in the $30^{\circ} \mathrm{C}$ growth chamber was smaller than in the $15^{\circ} \mathrm{C}$ growth chamber. 
Table 6. Effect of air and soil temperature and dry weight of satsuma mandarin roots in Experiment II (g).

\begin{tabular}{lccccc}
\hline \hline Air/Soil temprature & $\begin{array}{c}\text { Fibrous roots } \\
(\phi \leqq 2 \mathrm{~mm})\end{array}$ & $\begin{array}{c}\text { Small roots } \\
(2<\phi \leqq 5 \mathrm{~mm})\end{array}$ & $\begin{array}{c}\text { Large roots } \\
(\phi>5 \mathrm{~mm})\end{array}$ & Taproots & Total \\
\hline $15 / 15^{\circ} \mathrm{C}$ & 3.58 & 1.78 & 5.93 & 8.69 & 18.95 \\
$15 / 20^{\circ} \mathrm{C}$ & 6.65 & 2.35 & 9.73 & 11.78 & 29.70 \\
$15 / 25^{\circ} \mathrm{C}$ & 6.47 & 3.01 & 12.72 & 12.17 & 33.75 \\
$15 / 30^{\circ} \mathrm{C}$ & 8.44 & 3.12 & 13.33 & 16.14 & 40.43 \\
$30 / 15^{\circ} \mathrm{C}$ & 5.04 & 3.17 & 10.90 & 14.39 & 32.94 \\
$30 / 20^{\circ} \mathrm{C}$ & 9.10 & 2.80 & 7.39 & 13.99 & 32.61 \\
$30 / 25^{\circ} \mathrm{C}$ & 14.19 & 4.12 & 9.87 & 13.90 & 41.30 \\
$30 / 30^{\circ} \mathrm{C}$ & 14.94 & 6.74 & 15.19 & 14.44 & 50.55 \\
Significance & & & & $\mathrm{ns}$ & $*$ \\
- Air & $* *$ & $*$ & $\mathrm{~ns}$ & $\mathrm{~ns}$ & $\mathrm{~ns}$ \\
- Soil & $* *$ & $\mathrm{~ns}$ & $* *$ & $\mathrm{~ns}$ \\
-Interaction & $\mathrm{ns}$ & $\mathrm{ns}$ & $* *$ & ns \\
\hline
\end{tabular}

${ }^{z}$ ns indicates non-significant at $5 \%$ level; * significant at $5 \%$ level; ** significant at $1 \%$ level.

Table 7. Effect of soil temperature on bud development of satsuma mandarin in Experiment I .

\begin{tabular}{ccccc}
\hline $\begin{array}{l}\text { Soil } \\
\text { temperature }\end{array}$ & $\begin{array}{c}\text { Flower } \\
\text { buds }\end{array}$ & $\begin{array}{c}\text { Vegetative } \\
\text { shoots }\end{array}$ & Total & $\begin{array}{c}\text { Ratio of } \\
\text { flower buds } \\
\text { to total } \\
\text { sprouting }\end{array}$ \\
\hline $15^{\circ} \mathrm{C}$ & $48.33 \mathrm{a}^{2}$ & $41.33 \mathrm{~b}$ & $98.67 \mathrm{~ns}$ & $53.68 \mathrm{a}$ \\
$20^{\circ} \mathrm{C}$ & $25.67 \mathrm{~b}$ & $51.67 \mathrm{~b}$ & 77.33 & $33.24 \mathrm{~b}$ \\
$25^{\circ} \mathrm{C}$ & $16.67 \mathrm{~b}$ & $95.00 \mathrm{a}$ & 111.67 & $15.20 \mathrm{c}$ \\
$30^{\circ} \mathrm{C}$ & $0.67 \mathrm{c}$ & $84.00 \mathrm{a}$ & 84.67 & $0.75 \mathrm{~d}$ \\
\hline
\end{tabular}

z The same as Teble 1.

y Air temperature was $25^{\circ} \mathrm{C}$.

Figure 1 illustrates that the number of sprouting buds per node, the number of flower buds per node on spring shoots, and the ratio of flower buds to total sprouting buds at an air temperature of $30^{\circ} \mathrm{C}$ were smaller than at an air temperature of $15^{\circ} \mathrm{C}$. At an air temperature of $30^{\circ} \mathrm{C}$ these numbers decreased as soil temperature increased from 15 to $25^{\circ} \mathrm{C}$. They also decreased when the air temperature was $15^{\circ} \mathrm{C}$ and the soil temperature increased from 20 to $25^{\circ} \mathrm{C}$.

Mineral Nutrient Contents

Foliar analysis of spring leaves (about 7 months old) revealed that the mineral nutrient contents were comparable to those commonly found in satsuma mandarin leaves(20). The effects of temperature on mineral nutrient content in the spring leaves were slight (data was not shown).

Table 8. Effect of air and soil temperature on bud development on each cycle of shoots of satsuma mandarin in Experiment II.

\begin{tabular}{|c|c|c|c|c|c|c|c|c|c|c|c|}
\hline \multirow{2}{*}{$\begin{array}{l}\text { Air/soil } \\
\text { temperature }\end{array}$} & \multicolumn{5}{|c|}{ Flower Buds } & \multicolumn{5}{|c|}{ Vegetative Buds } & \multirow{2}{*}{$\begin{array}{l}\text { Grand } \\
\text { Total }\end{array}$} \\
\hline & Trunk & Spring & Summer & Autumn & Total & Trunk & Spring & Summer & Autumn & Total & \\
\hline $15 / 15^{\circ} \mathrm{C}$ & 0.00 & 95.33 & - & - & 95.33 & 0.67 & 67.67 & - & - & 68.33 & 164.67 \\
\hline $15 / 20^{\circ} \mathrm{C}$ & 0.00 & 143.33 & - & - & 143.33 & 1.00 & 65.00 & - & - & 66.00 & 209. 33 \\
\hline $15 / 25^{\circ} \mathrm{C}$ & 0.00 & 48.00 & 3.67 & - & 51.67 & 0.00 & 31.67 & 39.33 & - & 69.67 & 121.33 \\
\hline $15 / 30^{\circ} \mathrm{C}$ & 0.00 & 38.33 & 3.00 & - & 41.33 & 0.00 & 35.00 & 39.33 & - & 74.33 & 115.67 \\
\hline $30 / 15^{\circ} \mathrm{C}$ & 0.00 & 29.67 & - & - & 29.67 & 18.67 & 22.00 & - & - & 40.67 & 70.33 \\
\hline $30 / 20^{\circ} \mathrm{C}$ & 0.00 & 12.33 & 0.00 & 0.00 & 12.33 & 5.00 & 21.00 & 6.67 & 7.00 & 39.67 & 52.00 \\
\hline $30 / 25^{\circ} \mathrm{C}$ & 0.00 & 0.00 & 0.00 & 0.00 & 0.00 & 0.33 & 13.33 & 20.67 & 13.33 & 47.67 & 47.67 \\
\hline $30 / 30^{\circ} \mathrm{C}$ & 0.00 & 0.00 & 0.00 & 0.00 & 0.00 & 0.67 & 19.33 & 25.00 & 17.00 & 62.00 & 62.00 \\
\hline \multicolumn{12}{|l|}{ Significance ${ }^{z}$} \\
\hline -Air & & $* *$ & & & $* *$ & & & & & $*$ & $* *$ \\
\hline -Soil & & $* *$ & & & $* *$ & & & & & ns & $*$ \\
\hline -Interaction & & $* *$ & & & $* *$ & & & & & ns & $* *$ \\
\hline
\end{tabular}

${ }^{z}$ ns indicates non-significant at $5 \%$ level; * significant at $5 \%$ level, ** significant at $1 \%$ level. 

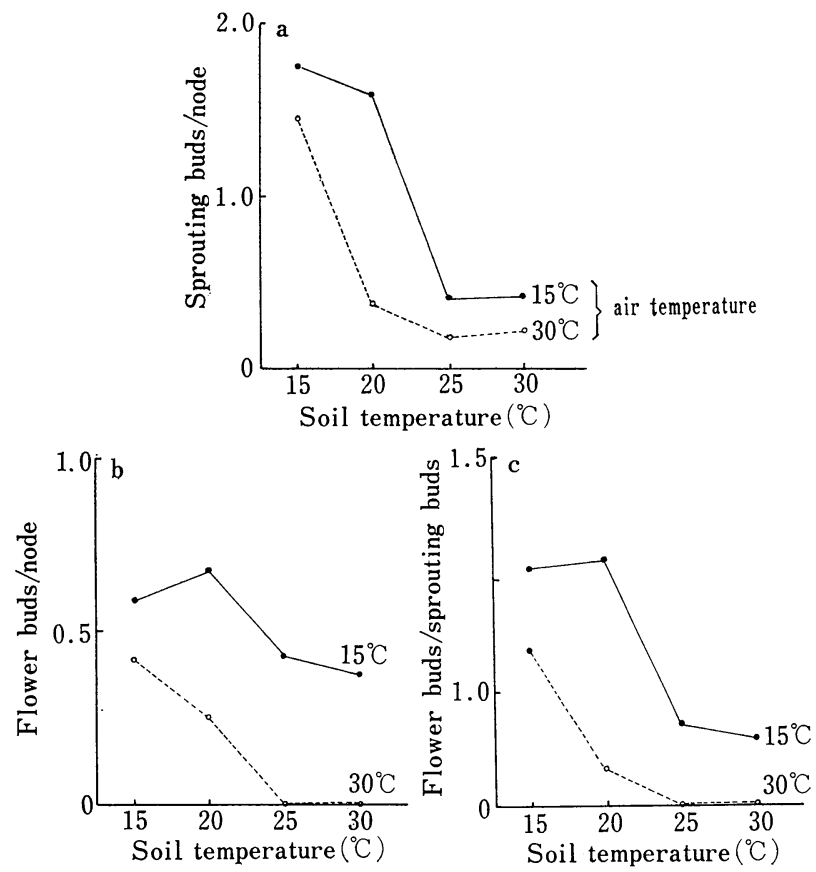

Fig. 1. Effect of air and soil temperature on the number of sprouting buds per node (a), number of flower buds on spring shoots per node (b), and the ratio of flower buds to total sprouting buds (c).

\section{Discussion}

Strong effects of soil temperature on vegetative growth and flower bud differentiation were observed. The number of flushes and the length of the shoots increased with rising soil temperatures in both experiments. These results agreed with those reported by Liebig and Chapman(11) and Khairi and Hall(9). When soil temperatures were above $20^{\circ} \mathrm{C}$, the number of flushes at an air temperature of $15^{\circ} \mathrm{C}$ was less than at $30^{\circ} \mathrm{C}$. The length of spring shoots at air temperature of $15^{\circ} \mathrm{C}$ was longer than at $30^{\circ} \mathrm{C}$, because the duration of growth of spring shoots at $15^{\circ} \mathrm{C}$ was longer than at $30^{\circ} \mathrm{C}$. However, the total length of the shoots did not differ between the two treatments.

Root growth of satsuma mandarin always followed shoot growth. When the spring shoots flushed, the root systems of all the trees were uniform because new roots did not developed before flushing $(7,17)$. It may be due to high transpiration and an imbalance between water absorption and transpiration that the growth of the spring shoots was limited at an air temperature of $30^{\circ} \mathrm{C}$. Borchert(2) defined a balance between the surface of water uptake in the root system and the surface of transpiration in the shoot system. The limitation of water absorption arrested shoot growth until enough roots were produced to achieve a balance.

At an air temperature of $30^{\circ} \mathrm{C}$, flower buds developed only at soil temperatures of 15 and $20^{\circ} \mathrm{C}$. At an air temperature of $15^{\circ} \mathrm{C}$, flower buds developed even when the soil temperature was $30^{\circ} \mathrm{C}$. Before they were defoliated and transferred to $25^{\circ} \mathrm{C}$, flower buds had already developed on all trees at the low air temperature $\left(15^{\circ} \mathrm{C}\right)$, whether the soil temperature was low $\left(15^{\circ} \mathrm{C}\right)$ or high $\left(30^{\circ} \mathrm{C}\right)$, and on the trees at the moderate air temperature $\left(25^{\circ} \mathrm{C}\right)$ with low soil temperature $\left(15^{\circ} \mathrm{C}\right)$. After defoliation, flower buds formed on trees grown at high air temperatures and low soil temperatures, or when both air and soil temperatures were moderate. No flower buds formed when high air temperatures were combined with moderate or high soil temperatures, or when moderate air temperatures were combined with high soil temperatures. It seems that low temperatures, either air or scil, induced flower bud differentiation. The effect of low air temperatures on flower induction was diminished when soil 
temperatures were high. Likewise, the effect of low soil temperatures on flower induction was lessened by high air temperatures.

The trees at $30 / 15^{\circ} \mathrm{C}$ did not bear flower buds before they were defoliated and transferred to $25^{\circ} \mathrm{C}$. Our defoliation technique in the warm room $\left(25^{\circ} \mathrm{C}\right)$ was employed to force the buds to sprout. This enabled us to compare the number of buds which had potentiality to sprout among the different temperature treatments. It seems that the trees at $30 / 15^{\circ} \mathrm{C}$ had flower buds of the lower inducted degree due to high air temperature. Moss (14) reported that high air temperatures inhibit flower development in sweet orange even after a period of inductive low temperature treatment. Hall et al(4) also re- ported that the number of flower buds of sweet orange developed at day air temperature of $30^{\circ} \mathrm{C}$ was markedly smaller than at $20^{\circ} \mathrm{C}$ under night air temperature conditions of $15^{\circ} \mathrm{C}$.

Since vegetative growth of the trees at $15 /$ 15 and $15 / 20^{\circ} \mathrm{C}$ was greatly inhibited, greater numbers of flower buds formed at these temperatures than at $15 / 25$ and $15 / 30^{\circ} \mathrm{C}$. At the latter two temperatures, flushing occurred both in spring and in summer. Inoue(6) and Inoue and Harada(7) reported that all satsuma trees grown at ambient temperatures of 15 and 20 ${ }^{\circ} \mathrm{C}$ had sprouting flushes only in the spring, and the resultant shoots produced some flower buds. At higher temperature when summer and autumn flushes occurred, flower buds were not produced. Moss(13) also reported that flowering in sweet orange trees occurs whenever shoot growth commences after the trees brought to warm condition.

Goldschmidt and Monselise(3) suggested that the flowering of citrus trees requires reduced levels of gibberellin. That trees at 15/25 and $15 / 30^{\circ} \mathrm{C}$ produced flower buds may be caused by decreasing gibberellin activity by low air temperature. And the formation of flower buds on all the trees grown at $30 / 15$ and $30 / 20^{\circ} \mathrm{C}$ may be caused by a reduction of gibberellin export from the roots. Yamada et al(21) reported that gibberellin levels in the stems of citrus trees grown at $13^{\circ} \mathrm{C}$ soil temperature were lower than in control trees (grown in greenhouse of Kyoto University in October). Atkin et al(1) also found that in maize, the export of total gibberellin and cytokinin from root to shoot increased at warm soil temperatures, while the inhibitor export decreased.

Since almost all mineral nutrient contents in the spring leaves ranged at medium levels and the effects of air and soil temperature on these contents were small, mineral nutrient content probably did not influence plant response to temperature. Labanauskas et al (10) reported that the nutrient contents in tops and roots of sweet orange seedlings were not affected by two soil temperature values (22.5 and $27.8^{\circ} \mathrm{C}$ ). Khairi and $\mathrm{Hall}(9)$ also reported that air temperature did not have a significant effect on the status of most mineral nutrients in leaves of sweet orange. However, Inoue and Harada(6) found that mineral absorption by satsuma mandarin increased as ambient temperatures rose from 15 to $25^{\circ} \mathrm{C}$, but decreased slightly at $30^{\circ} \mathrm{C}$.

\section{Literature Cited}

1. Atkin, R. K., G. E. Barton, and D. K. ROBINSON. 1973. Effect of root-growing temperature on growth substances in xylem exudate of Zea mays. J. Exp. Bot. 24: 475-487.

2. BORCHERT, R. 1973. Simulation of rhythmic tree growth under constant conditions. Physiol. Plant. 29: 173-180.

3. Goldschmidt, E. E. and S. P. Monselise. 1972. Hormonal control of flowering in citrus and some other woody perennials. p. 758-766. In: CARR, D. J. (ed.) Plant growth substances 1970. Springer-Verlag, Berlin.

4. Hall, A. E., M. M. A. Khairi and C.W. ASBELL. 1977. Air and soil temperature effects on flowering of citrus. J. Amer. Soc. Hort. Sci. 102: 261-263.

5. INOUE, H. 1984. Effect of soil drought and temperature on flower bud differentiation of satsuma mandarin. Abstr. Japan. Soc. Hort. Sci. Autumn Meet. 1984. 30-31. (In Japanese)

6. INOUE, H. 1989. Differentiation and development of flower buds in satsuma mandarins under different temperature conditions. J. Japan. Soc. Hort. Sci. 58: 75-82 (In Japanese with English summary).

7. Inoue, $H$. and Y. HARAda. 1988. Tree growth and nutrient absorption of young satsuma mandarins under different temperature conditions. J. Japan. Soc. Hort. Sci. 57: 1-7 (In Japanese with English summary).

8. IWASAKI, T., A. OWADA and Y. IIYA. 1959. Studies on the dfferentiation and development 
of the flower bud in citrus. I-IV. Bull. Tokai Kinki Agric. Exp. Stn. Hortic. 5: 1-76 (In Japanese with Englisn summary).

9. Khairi, M. M. A., and A. E. HAll. 1976. Effects of air and soil temperatures on vegetative growth of citrus. J. Amer. Soc. Hort. Sci. 101 : 337-341.

10. Labanauskas, C. K., L. H. Stolzy, L. J. Klotz, and T. A. DeWolfe. 1965. Effects of soil temperature and oxygen on the amounts of macronutrients and micronutrients in citrus seedlings (Citrus sinensis var. Bessie). Soil Sci. Soc. Proc. 29: 60-64.

11. Liebig, G. F. and H. D. Chapman. 1963. The effect of variable root temperatures on the behavior of young navel orange trees in a greenhouse. Proc. Amer. Soc. Hort. Sci. 82 : 204-209.

12. Monselise, S. P. 1973. Recent advances in the understanding of flower formation in fruit trees and its hormonal control. Acta Hortic. 34 : 157-166.

13. Moss, G. I. 1969. Influence of temperature and photoperiod on flower induction and inflorescence development in sweet orange (Citrus sinensis L. Osbeck). J. Hort. Sci. 44 : 311-320.

14. Moss, G.I. 1976. Temperature effects on flower initiation in sweet orange (Citrus sinensis). Aust. J. Agric. Res. 27: 399-407.

15. NIR, I., R. GOREN and B. LESHEM. 1972.
Effects of water stress, gibberellic acid and 2chloroethyltrimethylammoniumchloride (CCC) on flower differentiation in 'Eureka' lemon trees. J. Amer. Soc. Hort. Sci. 99: 774-778.

16. POERWANTO, R. 1987. The effects of temperature on the vegetative development of satsuma mandarin. M. S. Thesis, Graduate School of Agriculture, Kagawa Univ., Kagawa.

17. Poerwanto, R., H. InOUe and I. Kata. OKA. 1989. Effects of temperature on the morphology and physiology of the roots of trifoliate orange budded with satsuma mandarin. J. Japan Soc. Hort. Sci. 58 : 267-274

18. Southwick, S. M. and T. L. DAVEnPorT. 1986. Characterization of water stress and low temperature effects on flower induction in citrus. Plant Physiol. 81: 26-29.

19. SOUTHWICK, S. M. and T. L. DAVENPORT. 1987. Modification of the water stress-induced floral response in 'Tahiti' lime. J. Amer. Soc. Hort. Sci. 112: 231-236.

20. TAKAHASHI, E., M. Yoshino, and $M$. MAEDA. 1983. Nutrient deficit and excess symptoms for crop plants, p. 242-243. Nosangyoson Bunka Kyokai, Tokyo. (In Japanese).

21. Yamada, H., H. MuKai, N. UtsunomiYa, A. Sugiura and T. TOMAna. 1985. The effect of low root temperature on the cold hardiness of citrus species and avocado. J. Japan. Soc. Hort. Sci. 53: 419-436 (In Japanese with English summary).

\section{ウンシュウミカンの栄養生長と花芽分化に及ぼす気温と地温の影響 \\ ルディ プルワント・井上 宏・生駒吉識・片岡郁雄 \\ 香川大農学部 761-07 香川県木田郡三木町}

\begin{abstract}
摘
1 年生カラタチ台ウンシュウミカン ‘興津早生’ (Citrus unshiu Marc. cv. Okitsu Wase) を種々の気 温（実験 I : $25^{\circ} \mathrm{C}$, 実験 II : $15,30^{\circ} \mathrm{C}$ ) と地温 $(15,20$, $\left.25,30^{\circ} \mathrm{C}\right)$ を組久合わせた温度条件下で 4 月から 6 また は 7 只間生育させ，栄養生長，花芽分化，春葉の肥料 要素含量に及ぼす気温と地温の影響を調査した。

地温が高くなるほど新梢の生長周期および総伸長量は 増加した，同一地温条件下では，春枝の伸長量は低気温 区の $15^{\circ} \mathrm{C}$ 区で, 高気温区の $30^{\circ} \mathrm{C}$ 区よりも大となったが, $15^{\circ} \mathrm{C}$ 区よりも $30^{\circ} \mathrm{C}$ 区で新梢の生長周期が多くなったため, 新梢の総伸長量には差がみられなかった。乾物重は高気
\end{abstract}

\section{要}

温または高地温区ほど大となる傾向を示した，花芽は気 温もしくは地温のどちらかが低くなれば分化した。すな

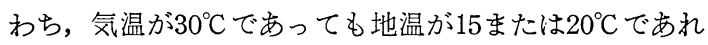

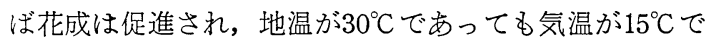
あれば花蕾の発生が認められた。気温と地温の組み合わ せが $25 / 30$ (気温/地温), $30 / 25,30 / 30^{\circ} \mathrm{C}$ の場合には, 花蕾の発生は全く認められなかった。春葉の肥料要素含 量に及ぼす気温または地温の影響は小さかった，栄養生 長ならびに生殖生長に関する気温と地温の役割について 考察した. 